\title{
Svět Magnuna. Esej o bláznivých rajčatech a čekání na revoluci ve Vítězné Káhiře
}

\author{
VÁClaV CÍlek \\ The World of Magnuna. Essay on Crazy Tomatoes and Waiting for a Revolt in Cairo \\ Victorious
}

\section{Rajčata jako nebezpečná metafora}

Počátkem listopadu 2010 konečně spadla cena rajčat v Káhiře na přijatelné tř̌i egyptské libry (asi 10 Kč) za kilo. Ještě týden před tím dosahovala cena kolem 10-12 liber a místní vzpomínali na celkem nedávnou dobu, kdy na předměstí Káhiry šlo koupit za libru tři kila rajčat. V podstatě se dá říct, že během tří let byl rozdíl mezi nejnižší a nejvyšší cenou rajčat zhruba třicetinásobný. Je to asi jako kdybychom v Čechách jednou zaplatili za bochník chleba dvacet korun a podruhé šest set. Proto se pro rajčata ujala přezdívka „magnuna“, což znamená „blázni“.

Něco podobného se stalo před pár měsíci s plynem. Běžný člověk vaří na plynu. Elektřina není zavedena všude a dřevo je drahé. Navíc i na obyčejných prknech naleznete švédská razítka, v horším případě nejprve českou cedulku země původu a pak švédský exportní štempl. Kus Šumavy tak máme i v Egyptě. Plyn byl subvencovaný státem, ale stát špatně platil arabským exportérům z okolních zemí a tak mu plyn prostě přestali dodávat, protože viděli, že Egyptané se placením nechtějí zabývat. Ceny nejprve stouply na desetinásobek a pak plyn došel, anebo byl na černém trhu za nehorázné ceny. Miliony nejchudších lidí přestaly na několik týdnů připravovat teplé pokrmy.

Stavuji se u obchodníka Mahmúda. Je to tak trochu manažer, trochu umělec, který vytváří patchworky, tedy textilní obrazy sešité z kousků látek. Vede rodinnou dílnu, ale pracuje pro něj asi deset dalších umělců. Patchwork je původní umění místních beduinů a obecně všech chudých lidí třeba ve Skotsku nebo v Arizoně, kteří se naučili šetřit každým kouskem látky. Je to jedna z mála věcí, které z tradičních řemesel zůstala, a to jen proto, že je kupují místní lidé. Tím se udržuje i původní kvalita produkce, protože nevzdělaní turisté mají tendenci kupovat laciné, nekvalitní zboží. Asi jak když u nás turisté ztratili zájem o opravdové obrázky a místo nich začali kupovat počítačové „printy“.

Říká mi: „Nevím, co bude. Ceny bavlny stoupají každý týden. Inflace je od jara možná kolem deseti procent. Většina mých lidí má už ted’ peníze jenom na jídlo, na nic jiného to nestačí.“ Problém nastane, když je třeba koupit léky nebo se něco porouchá. Staletí chudoby daly v Egyptě vzniknout systému rodinných půjček a sousedské pomoci, jaká třeba před desetiletími fungovala např́iklad v Ostravě. Půjčovat si v bance je nebezpečné, drahé a chudákovi stejně nikdo nepůjčí. Kdo chce pomoci světu, at se stane chudým bankéřem své ulice a at jej ti bohatí bankéři nezmlátí!

\section{Útěcha carského důstojníka}

Během čtyř let jsem po osmé v Egyptě. Pozoruji lidi a zároveň s kolegy přírodovědci a egyptology zpracováváme environmentální historii posledních několika tisíciletí. 
Egypt se pro podobná studia hodí snad nejlépe ze všech zemí světa, protože má nejdelší psanou historii světa a protože pouštní klima uchovává celá tisíciletí semínka rostlin, kousky dřev, vysušené brouky a další materiál, ze kterého se dají vyčíst proměny krajiny. Např́íklad nepálené cihly se dají u významných staveb datovat s přesností na deset let a jsou přitom plné makrozbytků. Stačí rozplavit, vybrat uhlíky, semena, fytolity (to jsou drobné, obvykle opálové „trámečky“, které zpevňují lodyhy trav a dalších rostlin), měkkýše, drobné kostičky, „pourčovat“ a interpretovat původní prostředí.

Téměř jsme si navykli dívat se na Egypt jako na sérii environmentálních kolapsů, kdy po několika staletích relativní stability přijde nějaká silná vlna aridity. Nil ztratí část svých vod a na poušti vyschnou některé prameny. Dojde pak k takzvanému přechodnému období, kdy se společnost na 100-200 let propadne do chaosu, kdy není co jíst a všechny dobré zvyky jsou pošlapány.

Rozpad centrální moci však může být doprovázen právě naopak určitým posílením periferních oblastí. Ukazuje se něco velice nadějného. Sociální kolaps spuštěný klimatickou změnou nemá charakter neúprosného osudu, ale dá se mu někdy vzdorovat a jindy jej dokonce využít $\mathrm{k}$ dalšímu rozvoji. Tak od oka bych ale řekl, že poměr úspěšného a neúspěšného přežívání nebude větší jak 20:80. Pokud bychom tento odhad aplikovali na současný Egypt se zhruba sto miliony obyvatel, tak při dalším možném přechodném období by smrtí hladem, nemocemi a násilím bylo ohroženo kolem 80 milionů obyvatel.

Nejhorší na tom všem je, že prakticky všichni z nás, kteří máme Egypt rádi a trochu jej známe, ve vzduchu cítíme, že se něco chystá. Nevíme, co a kdy se to stane. Nejsme z rodu těch lidí, kteří rádi vytvářejí apokalyptické scénáře, jen pozorujeme a vnímáme. Egyptologové mají jednu obrovskou výhodu - pracují s širokou škálou místních lidí od nejprostších kopáčů až po inspektory a poměrně vysoko postavené úředníky památkového úřadu a se všemi řeší nějaké praktické záležitosti, jako je pevnost betonu na střeše nově rekonstruované hrobky nebo zápůjčky předmětů $z$ různých skladů. Intenzivně a každodenně tak probíhá výměna informací, pocitů a postojů k životu.

Pocit, že něco „je na spadnutí“ můžeme snadno bagatelizovat odkazem na carské důstojníky-bělogvardějce, kteří se v Berlíně v roce 1922 navzájem ujištovali, že to Leninův režim nemůže dlouho vydržet, že zkolabuje a oni se vrátí. Kolaps, ale jenom režimu, nikoliv celé společnosti skutečně o 70 let později nastal, ale přechodné období se odehrálo během deseti let a nemělo charakter hladomoru, jen důrazné mentální proměny světa. Vše nakonec bylo jinak (a mnohem lepší), než to v roce 1922 vypadalo. Stačí však i povrchní znalost povstání v Súdánu, masakrů v Damašku, mnohokrát zničeného Jeruzaléma či Libye vylidněné po válkách s Vandaly, aby člověk jasně vnímal i možnou temnou stránku budoucnosti.

\section{Spojnice mezi ropou a potravinami}

Odhlédneme-li od pocitů, co konkrétního se o egyptské situaci dá říct? Je tu především průběh ropné krize v letech 2007-2008, kdy cena ropy dosáhla 147 dolarů za barel. Ropa je nejslabším článkem energetického řetězu, protože poptávka a nabídka jsou zhruba v rovnováze, a pokud by měla poptávka růst stejným tempem jako v průběhu současné západní ekonomické krize, můžeme se během tří až pěti let dostat do relativně velkého problému. 
Ten ani tak nebude spočívat v nedostatku samotné ropy, které může na světovém trhu chybět přibližně kolem 2-3 (maximálně 5) procent, ale v panice, s jakou odhalíme vlastní závislost. Něco podobného si Egyptané uvědomili u těch rajčat, když zjistili, že je cpou do většiny jídel a že se bez nich těžko mohou obejít. A co jsou rajčata proti takovému benzínu! Velice pravděpodobně dojde k přestřelení cen, což pravidelně vídáme u všech komodit, jichž se nedostává.

Ceny energie jsou zatím navzájem propojeny bez ohledu na zdroj. Je jedno, jestli elektřinu vyrobím z uhlí, plynu nebo ropy. Zatím to znamená, že vyšší ceny jednoho zdroje, třeba plynu automaticky zvýší ceny všech ostatních energetických zdrojů. A opět určitá naděje spočívá v tom, že se ekonomům a energetikům podaří ceny uhlí, plynu a ropy od sebe separovat, takže neklid $\mathrm{v}$ jedné oblasti se automaticky nepřesune do celé energetiky. Zatím se to v posledním roce děje u plynu, kterého je relativní nadbytek, a u ropy, kde tomu je právě naopak.

Energetika je úzce propojena s potravinami. Zhruba 40 \% (někdo uvádí až 48 \%) světové produkce potravin závisí na umělých hnojivech, herbicidech a pesticidech. Základní umělé hnojivo je dusičnan amonný, který se vyrábí energeticky náročnou HaberBoschovou syntézou dusíku a vodíku na amoniak a odtud na dusičnan. Vysoké ceny ropy tedy způsobí vysoké ceny hnojiv a tím i potravin. To vše se odehrává ve státě, kde odhadem dvě třetiny lidí už ted’ utrácí $70-90 \%$ svých příjmů za jídlo. V okamžiku, kdy ropa dosáhne 150 dolarů za barel, může reálně dojít ke zvýšení cen potravin a vlastně všeho o 20 \% , čímž se polovina Egypta octne za hranicí zoufalství, jako muž, jenž před dvěma lety marně celý den čekal na levný, subvencovaný chléb a když jej nedostal, tak otrávil celou svoji rodinu. V Káhiře toho byly plné noviny.

Pozorovali jsme tehdy neklid u státních pekáren. Bylo jasně cítit, že zde o něco jde. Zoufalství bylo vidět ve tvářích asi jako v sociálních grafikách Jana Rambouska a Kolomana Sokola z dob velké krize. Člověk si snadno domýšlel tíživost domova a děti plačící hladem. Ve frontách docházelo ke rvačkám a objevili se první mrtví. Zhruba polovina státního obilí se přitom cestou k chudým ztratí na černém trhu. On totiž hladoví i inspektor přes hygienu a místní policista. Zavřeli by pekárnu, kdyby nic nedostali. Stále je třeba někoho uplácet. Vlastní rodina je velká. Pak ceny ropy spadly na 40 dolarů za barel a situace se vrátila do normálu. V posledním roce se ropa opět zvedla asi na 70-80 dolarů za barel, ale růst byl díkybohu pozvolný. Během dalších tř́i let by mě (ve shodě s renomovanými západními analytiky) nepřekvapily ceny kolem 150-200 dolarů za barel, ale místní lidé se dostávají do plíživé ekonomicko-potravinové krize již ted’.

V této situaci není Egypt sám! Vím, že v našem nepředpověditelném světě nesu s jakýmkoliv tak závažným odhadem, jako je očekávání potravinových bouří v Káhiře, kůži na trh, ale potřebuji, aby se o těchto věcech vědělo a přemýšlelo, takže jsem ochoten podstoupit osobní blamáž.

\section{Klimatická změna}

Opět se zabýváme motivem nedostatku rajčat, ale tentokrát je rozšířen na základní potraviny. Mimochodem rajčata se neurodila, protože letos byl v Egyptě neobvykle horký rok, takže by šlo ještě navíc uvažovat i o klimatické změně, ale nechci v této chvíli komplikovat situaci další neodhadnutelně proměnlivou veličinou. Snad jenom rámcově se dá říct, že nastávající klimatická perioda o délce trvání asi 30-40 let by na jednu stranu měla být 
víc rozkolísaná, ale také do severní Afriky přinést spíš nerovnoměrně vlhčí klima, protože průběh atlantské oscilace stlačuje tryskové proudění (Atlantic jet stream) dál na jih. Dlouhodobější perspektiva je spíš nadějná, pokud nepřijde větší regionální sucho, což se na Sahaře stává průměrně každých 30 let, anebo dokonce katastrofické sucho, které se odehrává každých zhruba 120 let.

Další důvod k obavám spočívá ve slabosti egyptské ekonomiky, která kromě turistiky, bavlny a pár dalších surovin a výrobků nemá světu co nabídnout, a tím pádem za co nakupovat potraviny. Egypt už dávno není vývozcem potravin a okolní arabské státy mu už nechtějí př́liš pomáhat. Lidí zde přibývá kolem milionu za rok, ale plocha zemědělské půdy se každým rokem zmenšuje a i ta zbývající podléhá degradaci zasolováním a přehnojováním.

Půdy ubývá hlavně proto, že je zastavována. Egypt byl považován za přelidněný už v dobách, kdy měl dvacet milionů obyvatel. V poušti sice vznikají satelitní městečka, ale to abyste měli auto na dojíždění do práce. I tak autobusy a mikrobusy každé ráno do Káhiry dopravují kolem 2-4 milionů venkovských obyvatel, tedy dvakrát tolik, než kolik měl obyvatel faraonský Egypt.

\section{Mizející půda}

Asi 60 \% egyptské produkce potravin pochází z Delty. V noci z letadla vypadá Delta jako jedno velké předměstí. Všude jsou nějaká světla. Ve dne je pocit ještě horší. Delta je hrozně zadrátovaná, všude vedou kabely do vesnic a městeček, které jsou kousek od sebe jako domy v Holandsku. Jenom u nás v Abusíru žije v místní vesnici 45-55 tisíc lidí, ale v Deltě jsou prý vesnice o 200 tisících lidech. Tento typ sídel nemá žádnou analogii. Není to město, protože schází běžné městské atributy jako je náměstí, specializovaná dělba práce či radnice, ale také to není vesnice, protože přece jenom ve středu sídla vzniká cosi jako ulice a objevuje se pár dílen. V 90. letech minulého století se uvádělo, že průměrná rodinná farma měla kolem 1,6 feddanu (feddan je 0,42 ha), ale že 95 \% farem měla jen 0,9 feddanu. Nyní je situace ještě tíživější, takže průměrná rodina hospodaří na 0,2 ha. To můj děd v Lázních Bělohradu měl průměrné hospodářství asi na 18 ha půdy.

Většina domů, které člověk vidí podél cesty, je mladších dvaceti let. Typicky majî betonový skelet vyplněný cihlami. Cihly se vyrábí z orné půdy. Takže domy berou půdu dvakrát - poprvé na plochu stavby, podruhé na cihly. Cihly by šly řešit jako cementpískové cihly, protože cementu i písku je dost. Napadlo mně to, když jsem zpracovával poměrně odolné pískové cihly z velké mastaby odkryté prof. Bártou (V. dynastie). Staří Egyptané dokázali vyrábět pískové cihly prolévané sádrovým mlékem.

V roce 1964 byla dokončena Asuánská přehrada, čímž přestaly pravidelné záplavy, které přinášely úrodné bahno. Upřímně řečeno, úrodné bahno je trochu mýtus. Jako hnojivo by nestačilo ani na jednu sklizeň, proto se na požaté pole vyháněl dobytek a nevyužitá sláma byla spalována v rámci hnojení popelem. Mýtus však není zasolování a kontaminace půdy. Pravidelné záplavy pole přece jenom proplachovaly a zbavovaly solí. Vláda se tehdy cítila trochu vinna výstavbou přehrady, a proto zemědělcům subvencovala (a dělá to ve velké míře dodnes) vodu, hnojiva a herbicidy. Díky subvencím se Egypt rychle stal zemí s největší spotřebou hnojiv a zemědělských chemikálií na světě. Je tak jednoduché líně rozhazovat hnojiva po poli, když je nemusím platit. Jejich 
zbytky přecházejí do potravin, takže řada států zakázala dovoz jakýchkoliv egyptských potravin.

Není zde místo na diskuzi kladů a záporů Asuánské přehrady, ale z čistě egyptologického hlediska to je faraon, který je vládcem Nilu, respektive je ztělesněním určitého řádu, který se odráží v ničivosti záplav. Za stavbou přehrady se tak dá cítit i staroegyptský mýtus o božském vládci a moudré vládě. Prezident se tak v symbolické rovině stává legitimním pokračovatelem faraona. Do jeho velikosti mu však podle kamenných reliéfů ze Staré říše zbývalo jediné - pokořit nepřátele. U Libyjců a Súdánců to už moc nejde, ale naštěstí Egypt sousedí s Izraelem. Stvrzení božské legitimizace však v letech po dokončení vodního díla nedopadlo úplně dobře.

\section{Voda slaná a sladká}

Každých pár desetiletí postihne Egypt ničivé sucho. Asuán zadrží vodu na zhruba dva suché roky, ale na víc nestačí. Nilské vody bude přicházet stále méně, protože se rozrůstá Etiopie i Súdán. Viděli jsme vykolíkované přehrady na súdánských kataraktech i čínské plány na zavlažování Geziry, tedy území mezi Bílým a Modrým Nilem. Část potravin zůstane v Súdánu, ale část přijde na export do Číny. Do Egypta přiteče méně vody a moře v Deltě bude dál tempem až $200 \mathrm{~m}$ za rok pohlcovat pobřeží. Strážní ottomanské věže dnes stojí daleko v moři. Slaná voda bude snadněji pronikat do podzemních zásobníků, stoupat k povrchu, odpařovat se a zanechávat za sebou zasolenou půdu. To není vize budoucnosti, to se už děje.

Rovněž pouštní projekty jsou nesmyslné, protože jsou drahé a spotřebují několikanásobky běžných závlah. Kapacita saharských podzemních zásobníků v núbijském pískovci je odhadována zhruba na 60 let. Občas se podaří získat novou zemědělskou půdu pro desítky tisíc lidí, ale obyvatelstvo přibývá po statisících. Zemědělští experti nejprve celá desetiletí rozvíjeli systémy závlahového hospodářství, ale pak v Libanonu a Saudské Arábii začali překvapivě razit názor, aby tyto poměrně vyspělé země opustily neefektivní pouštní farmy a raději potraviny dovážely. Založit farmu v Ugandě vyjde laciněji než v Západní poušti.

Je to stále stejný př́iběh. Na jedné straně přibývá lidí a na druhé straně ubývá vody a půdy. Emigrovat není kam. Arabská solidarita vždy váhá mezi nezištnou pomocí a nájezdem na oslabeného souseda. Bohatší a vnímavější egyptské rodiny, často to jsou Koptové, se snaží, aby se alespoň nějaký člen uchytil v Evropě či Americe a v nejhorším případě mohl vytvořit záchrannou archu pro další rodinné prríslušníky. Tito lidé jsou většinou šikovní, vzdělaní a mají daleko do fanatiků. Chtějí normálně žít.

\section{Muslimské bratrstvo}

Hovoříme s lidmi. Stále silnější je motiv nenávisti k vládě a policii. Jediná alternativa jsou radikálové, protože rozumné opoziční strany neexistují anebo jsou př́liš slabé a rozhádané. Muslimské bratrstvo zakládá nemocnice a školy a podporuje sociální programy. Zda to bude dělat, až se jednou chopí moci, nevím. Je v něm hodně nenávisti a také tradice zahleděné dozadu. Při tomto počtu lidí a v daném globálním kontextu bude země potřebovat nové jednoduché technologie čerpání vody, zpracování odpadků, vytváření energeticky soběstačných ostrovů, tedy otevřenou a do technologické budoucnosti zahleděnou vládu. To zatím radikálové (ani vláda) nesplňují. Myslím si, že hlavní vlna 
islamismu teprve přijde. Vidíme ji nastupovat. V 60. letech se z Egypta do Československa vozily minisukně. Dnes každým rokem roste počet zahalených žen a mužů s boulemi na čele (jak tlučou při modlitbě hlavou o zem). Běžný Egyptan je nemá rád, protože chce vést klidný rodinný život a modlit se k Alláhovi po svém. Iránská zkušenost ukazuje, že vlna extrémních nálad se zhruba po dvaceti letech vyčerpá. Pomohl by nějaký nepřítel, ale Izrael je přiliš silný, takže to asi odnesou Koptové. V globalizovaném světě je třeba dát přednost vnitřnímu nepříteli.

\section{Co dělat při sociálním kolapsu velké země?}

Tento článek pochopitelně píši proto, abych Egyptanům, mělo-li by dojít k nejhoršímu, nějak pomohl. Líbilo by se mi, kdybychom měli dobře rozmyšlenou strategii, co v takovém případě dělat. Především ve státech, jako je Egypt, je cítit sociální napětí. I když ještě v poledne to vypadá normálně, už ve čtyři může znenadání jako požár vypuknout masakr. Situace nás téměř určitě zaskočí. První vlna revoluce bývá velice živelná a krutá, ale Egyptané to dlouho nevydrží a začnou se rychle vracet do normálních kolejí. Je to v podstatě mírný národ, který vybuchne, ale chvíli na to už je v normální existenciální depresi.

Potíž je v tom, že takto velkou zemi nelze ze zahraničí uživit. Největší potravinovou pomoc zatím dávají výměnou za mír s Židy nenávidění Američané, ale i jejich síly jsou omezené. Tím spíš, kdyby klesající produkce potravin byla způsobena nějakou klimatickou událostí kontinentálního rozsahu. Ten by měl navíc téměř určitě nějaké dopady i na Evropě. Bud’ můžeme posílat nějaké peníze a potraviny a nechat konflikt vyhnít na místě, anebo uvážlivě přijmout uprchlíky. Na solidaritu, a to zejména dlouhodobou, nejméně 2-3 roky trvající podporu, bych se př́liš nespoléhal. Navíc bez (téměř neexistující) sítě místních organizací by nejméně polovina pomoci nikdy nedorazila k nejchudším.

Myslím, že se v dalších odstavcích budu pohybovat na samé hranici politické korektnosti. Vycházím z toho, že základním posláním každé kultury či civilizace je:

1. Zachránit sám sebe a rozvíjet přitom daný sociální, kulturní, duchovní i technický a zemědělský odkaz předků.

2. Teprve potom pomáhat ostatním, ale mít přitom na zřeteli první bod.

Při četbě římských autorů post-klasické doby si nelze nevšimnout stesků nad tím, že lidé, kteří dřív bývali Římané rodem, dnes pocházejí z různých koncủ říše. Nejedná se zde o žádný rasismus či xenofobii, ale o pozorování, že cizí etnika se řídí jinými zvyky, a tím oslabují ty hodnoty, díky nimž státy vznikly a jsou udržovány. Stanislav Komárek si v jedné eseji klade otázku, k čemu jsou nám svobody, které způsobují konec té společnosti, která je propaguje. Chci tím říct, že počet přistěhovalců by neměl být velký a měl by přednostně přicházet $z$ oblastí nám blízkých, jako je např́klad Slovensko, Ukrajina či od jižních Slovanů. Nemyslím si, že tato země by unesla jednorázový př́liv více než 30 tisíc emigrantů, protože $\mathrm{z}$ tohoto množství může být následkem velké porodnosti záhy sto tisíc lidí.

Pokud bychom měli přijímat uprchlíky z Egypta, soustředil bych se na mladé rodiny, to znamená kolem 10-12 lidí a přednostně bych volil Kopty. Jsou milí, pracovití a nadaní. Je zde velká šance, že by náš život duchovně i prakticky obohatili. Už dlouho se např́klad dívám po etniku, které by bylo schopné na českém poli vypěstovat dobrou domácí zeleninu. Ale Koptové jsou i dobří lékaři, právníci a ekonomové. To znamená, že bych udělal přesně to, o čem se dnes ještě nesmí př́liš hovořit - vědomě bych při 
přijímání uprchlíků volil náboženskou diskriminaci. Asi nejjednodušší by bylo poslat sociální pracovníky do jedné dvou oblastí a tam za pomoci místní samosprávy či náboženské správy odeslat části celých komunit. To by byl egyptský aspekt problému.

V Čechách by bylo nejlepší, kdyby města a obce nahlásily počet uprchlíků, které jsou ochotné přijmout. Asi není nic horšího než dlouhý, nejistý pobyt v nějakém utečeneckém táboře. Zároveň by se omezilo nebezpečí vzniku ghetta a mohlo by dojít k rychlejší integraci do společnosti. Rozptýlená koptská komunita by však za naší pomoci měla okamžitě založit nějaké centrum své identity, a tím by měl být klášter s malou tiskárnou a dílnou na ikony někde v české „pustině“. Máme jich dost na rozdávání. Napadá mně třeba Mariánská Týnice či příbramská Svatá hora nebo spíše jiné odlehlejší mariánské místo. Nejedná se tedy o rozplynutí se v české identitě, ale o ponechání si kusu vlastního srdce a přitom běžné fungování $\mathrm{v}$ rámci české společnosti. Tohle třeba docela dobře zvládají bosenští muslimové (jsme z jedné monarchie), ale obtížně se všude v Evropě přizpůsobují severoafričtí muslimové. Abych nemluvil jenom o křestanských Koptech, další sympatické, nám poměrně blízké a dobře se začleňující národy jsou například Palestinci a obecně Levantinci. Většina z nich má dost války, tvrdých náboženských forem a konfliktů všeho druhu, a tak je vděčná za možnost normálně žít. Alžiřrané a Maročané však v sobě nesou určitou hněvivost a neochotu přijmout jiný život.

\section{Provinilé oběti}

Na lidi postižené nějakým neštěstím obvykle myslíme jako na nevinnou obět. V Egyptě to tak úplně neplatí. Od konce 60. let se objevuje jedna západní analýza za druhou, co je třeba udělat. Nikdo jich nedbá, budoucnost je daleko a arabský postoj k ní vyjadřuje věta: „Nač si kazit hodinu, která právě je, pro tu, jež ještě nenastala.“ Egyptané celá desetiletí tvrdohlavě a paličatě všem navzdory žijí svůj život bez ohledu na svět, který se změnil. Nic se nenaučili, nic je nezměnilo. Platí na ně jediné dvě síly - karabáč vojenského režimu nebo moc úplatku. Jaký kus mentální cesty oproti nim ušli Turci, Peršané nebo Syřané!

Státy a monarchie padají chybami, ze kterých se neponaučily. Máme povinnost upozornit, ale nikdo po nikom nemůže chtít, aby jeho vlastní chyby padly na cizí hlavu. A přesto situace není tak jednoduchá, protože, málo platné, většina Egyptanů jsou milí lidé, pro které by si člověk ledacos odpustil. Rozum jasně ř́ká: Děláte chyby a zaplatíte za ně. Srdce však trne a prosí za ně.

\section{Skončila postmoderna, nastal svět Magnuna}

Abych to shrnul - hlavní důvody, proč čekám násilnou revoluci spojenou s hladomorem v Egyptě, jsou zvyšující se ceny energií, obrovské množství lidí, malá a zhoršující se zemědělská produkce, ubývající voda, ekonomicky neschopná vláda, napětí a nejistota mezi lidmi a rostoucí moc radikálů.

Města jako Jeruzalém, Damašek nebo Káhira nejprve vyrostou, otřesou se a padnou, ale pak se zase vítězně pozvednou. Antiochie či ještě víc Palmyra však varují před koncem, který je doopravdy konečný, a nikoliv počátkem dalšího cyklu. Procházíte Káhirou či Damaškem a cítíte, jak dozrává nějaký problém, ale zároveň tady pulzuje silná energie nahromaděné kultury, vzdělanosti a touhy žít a prodávat. Stále ještě v nich bydlí nějaký skutečný, živý bůh. Nicméně místa jako Káhira, Ammán a možná i Athény se dostávají na hranice svých možností, a to i kdyby byl svět neměnný a ceny stálé. 
Češi jsou národ, který se vejde do jednoho čínského provinčního města, jehož jméno jsme nikdy neslyšeli. Rádi myslí na sebe a moc se nestarají o vzdálenější svět, kterému se nenaučili rozumět, ostatně jako mnoho dalších národů. Jenže se všichni ocitáme ve světové epoše, kterou bych nazval bláznivou, svět Magnuna. Svět Magnuna je další fáze vývoje postmoderny. Kde je španělská konjunktura, kde je náš vzor Irsko, jak to, že světoví investoři se zbavují amerického dolaru a kupují českou korunu nebo jinou pofiderní měnu? Možná k žádným sociálním kolapsům nedojde (tř̌ebaže tomu nevěřím), ale turbulence jsou již ted’ silné, zatímco některé národy a státy spíš slábnou. Žádná analýza přitom nepočítá s tím, že potraviny a ropa budou v budoucnosti lacinější. Bojím se o Egypt.

\section{Poznámka}

Text píši po nocích a bez pomoci jakékoliv literatury v Káhiře Vítězné v listopadu roku 2010 při př́ležitosti výkopových prací v Abusíru. V Káhiře jsem díky projektu „Environmentální výzkum egyptské Západní pouště: případová studie týkající se úpadku civilizace způsobeného klimatickými změnami“, číslo M100130902. Děkuji tomuto projektu, bez kterého by text nevznikl, i když tento typ publikace stejně nemohu vykázat.

\section{Postskriptum z června 2011: Arabské probuzení}

Něco z budoucnosti se dá odhadnout a hodně ne. Čekali jsme někdy revoluci v Egyptě, ale určitě ne v Libyi a Sýrii. Netušili jsme, že podle arabských revolucí bude organizována velká květnová stávka ve Španělsku. Teprve, když sledujeme vysílání Al Džazíry, tak si uvědomujeme, že tento rok vstoupí do historie lidstva jako „Arabské probuzení“ a že bude mít nejspíš podobnou váhu jako evropské revoluce roku 1848 a evropská národní obrození. I ta měla stejné motivy - vír změn a sebeuvědomění si, ale různý průběh. V Čechách to byla pozitivní industrializace a tvorba kulturního národního prostředí, ale v Srbsku destruktivní nacionalismus, který pomohl rozpoutat první světovou válku.

V současném Egyptě vidíme politické a společenské procesy, které ve velmi zmírněné formě přicházejí i do České republiky. Je jím pozvolné zdražování věcí nezbytných k životu a zároveň snaha vlády (kterou jsme si jako všechny předešlé řádně zvolili) přenášet na občany čím dál víc plateb, a to včetně zbytečných a korupčních výdajů. Je jen otázka kolik takových plateb lidé ještě unesou a jaká bude pro nás krizová energetická hranice - 200 dolarů za barel ropy? Pak možná vyjdeme do ulic, ale moc platné nám to nebude, protože skutečný drak, se kterým svádíme boj, je globální trh energetických a potravinových komodit. V každém případě je zapotřebí dění v Egyptě důkladně sledovat, abychom lépe porozuměli tomu, co v nějakém českém vydání může přijít také k nám.

Ceny ropy i potravin výrazně rostly a stále zůstávají vysoké. Egyptská ekonomika s propadem turismu o 46 \% je na tom hưř než kdykoliv předtím. Dochází státní zásoby obilí. Pesimisté čekají druhou fázi revoluce již letos v létě, optimisté - jako já - spíš až na podzim. S bolestí v srdci prožíváme hledání náhradních viníků mezi násilně umírajícími Kopty. V druhé fázi by se mohlo jednat o nějaký spíš symbolický útok na Izrael. 